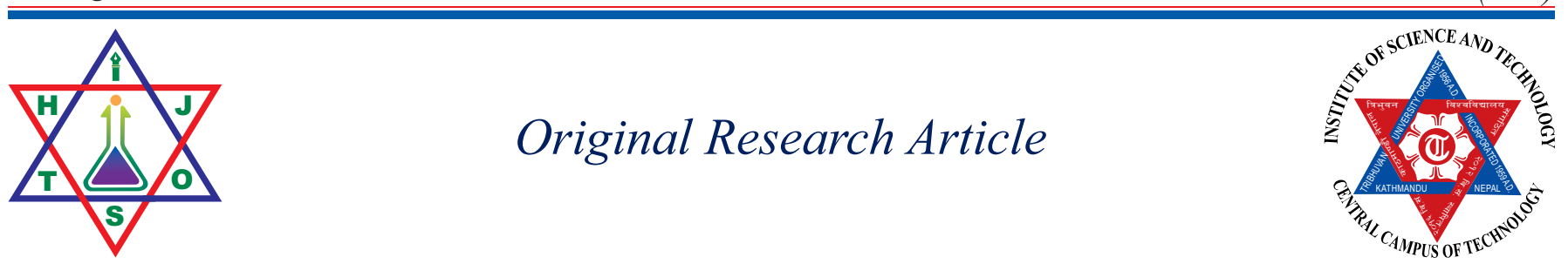

\title{
Ratio of soil microbial biomass carbon to soil organic carbon in Himalayan rangeland
}

\author{
Dil Kumar Limbu ${ }^{{ }^{*}}$ and Madan Koirala ${ }^{2}$
}

${ }^{1}$ Central Campus of Technology, Dharan, Tribhuvan University, Nepal

${ }^{2}$ Central Department of Environmental Science, Kirtipur, Tribhuvan University, Nepal

*Corresponding Author: Dil Kumar Limbu, Central Campus of Technology, Dharan, Tribhuvan

\begin{abstract}
:
The soil microbial biomass carbon to soil organic carbon ratio is a useful measure to monitor soil organic matter and serves as a sensitive index than soil organic carbon alone. Thus, the objective of this study is to identify and quantify the present status of ratio of soil microbial biomass carbon to soil organic carbon in Himalayan rangeland and to make recommendations for enhancing balance between microbial carbon and organic carbon of the soil. To meet the aforementioned objective, a field study was conducted from 2011 to 2013 following the Walkley-Black, Chromic acid wet oxidation method, and chloroform fumigation method for analysis of microbial carbon and organic carbon respectively. The study showed that the heavily grazed plothad significantly less value of ratio than occasionally grazed and ungrazed plots. The ratio was significantly high on legume seeding plot compared to nonlegume plot, but the ratio was independent of soil depth. Soil microbial biomass appeared to be more responsive than soil organic matter.
\end{abstract}

Key words: Biomass, Himalayan rangeland, Soil, Organic carbon, Microbial

\section{Introduction}

Organic matter, a major soil component, is critical for healthy soil. This organic matter includes living plants, animals, and microbes, litter on the soil surface as well as degrading and decomposing materials. It makes soils resilient by providing food for soil microbes, provides a store of relatively available nutrients, and bonds soil particles for a stable structure. Soil health of rangelands alters various management systems; grazing, burning, application of fertilizer and environmental changes. The maintenance of the organic matter content of soils is desirable for long-term land use because of the multiple beneficial effects of organic matter on nutrient status; water holding capacity and structure (Allison, 1973).

The living fraction of organic matter, the microbial biomass, rather than total amounts of organic carbon, has been suggested as a useful and more sensitive measure of a change in organic matter status (Powlson \& Jenkinson 1981; Powlson et al. 1987). Microbial biomass carbon is a measure of the carbon contained within the living component of soil organic matter.Soil microbial biomass carbon $(\mathrm{MBC})$ generally constitutes $1-5 \%$ of the total soil organic carbon (SOC) (Anderson and Domsch, 1989) which acts as the most active component in the biochemical process of SOC turnover (Paul and Clark, 1996), and responds more rapidly to soil disturbance than SOC does (Holt, 1997). Soil MBC, as an important indicator of changes of soil quality and management practices (Wang and Long, 2008), is very sensitive to environmental changes Nielsen et al, 2002). In grazing lands, organic input from vegetation and excreta of animal can contribute to increased soil organic matter content and consequently cause an impact on soil biological processes. Thus, soil microbial biomass plays a critical role in grazing ecosystems as there is a large input of organic residue. Therefore, to better understand $\mathrm{C}$ cycling, it is important to gain an understanding of the $\mathrm{MBC}$ content that is affected by grazing and the relationship between $\mathrm{SOC}$ and $\mathrm{MBC}$.

Grazing influences the amount and composition of burning soil organic matter (SOM) (Dormaar and Willms, 1990; Frank et al, 1995) through its effects on litter accumulation and decomposition (Naeth et al, 1991; Shariff et al, 1994). The extent to which different grazing practices alter C cycling and SOM composition is not well 
understood (Parton et al, 2001; Ganjegunte et al, 2005).

The objective of the present study was to find on microbial biomass carbon and soil organic carbon in Himalayan rangeland. Grazing experiment was conducted in a temperate grassland of Eastern Nepal to explore the ratio of soil microbial biomass $\mathrm{C}$ to soil organic carbon on various soil profiles and to test the hypothesis that grazing intensity alters the ratio of soil microbial biomass $\mathrm{C}$ to soil organic carbon in Himalayan rangeland.

\section{Materials and Method}

\section{Study Area}

The study was conducted in the Tinjure-Milke-Jaljale (TMJ) Mountain ridge-political border of three districts, i.e., Taplejung, Tehrathum and Sankhuwasabha of Eastern Nepal. Geographically the area lies between $27^{\circ} 6^{\prime}$ $57^{\prime \prime}$ to $27^{\circ} 30^{\prime} 28^{\prime \prime}$ North latitude and $87^{\circ} 19^{\prime} 46^{\prime \prime}$ to $87^{\circ} 38^{\prime}$

\section{4" East longitude (Fig. 1).}

The study area was established in 2011 in a randomized block design. Three experimental plots were fixed viz. (a) rangeland with heavily grazed (year round grazing) (b) rangeland with occasional grazed, and (c) ungrazed enclosures rangeland.

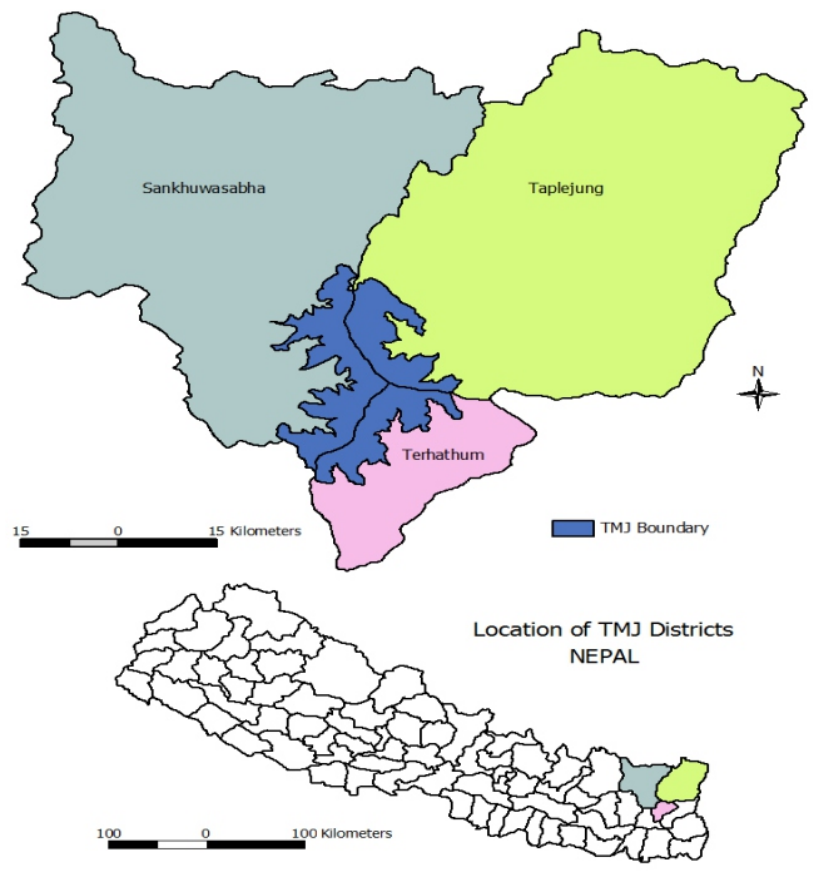

Fig. 1.Tinjure Milke Jaljale (TMJ) study area map.

Each plot was further divided into legume over-seeded sub-plot and non-legume sub-plot. Now, there were six sub-plots viz. heavily grazed legume (GL), heavily grazed non-legume (GNL), occasionally grazed legume (SGL), occasionally grazed non-legume (SGNL), ungrazed legume (UGL) and ungrazed non-legume (UGNL).At the end of 3 years grazing (late September $2013)$, ten sampling points were established in two parallel transect lines. One quadrat $(30 \mathrm{~cm} \times 30 \mathrm{~cm})$ was established at each sampling point. Within each quadrat, three soil cores were collected at depths of $0-5 \mathrm{~cm}$ (first soil profile), $5-10 \mathrm{~cm}$ (second soil profile) and $10-15 \mathrm{~cm}$ (third soil profile). Similarly, soil bulk density was determined for three different strata by using the core method (Blake \& Hartge, 1986).

\section{Soil Sampling}

Soil samples were collected from each sub-plot with the help of soil core having $4 \mathrm{~cm}$ diameter and $15 \mathrm{~cm}$ length. Soil core was separated into three sections viz. $0-5 \mathrm{~cm}$ (soil profile), $5-10 \mathrm{~cm}$ (second soil profile) and $10-15 \mathrm{~cm}$ (third soil profile) and sliced with $5 \mathrm{~cm}$ strata of each slice. Each slice of the soil was packed in separate zipped polythene bag, immediately placed in ice bank for transport to the laboratory and stored at $4^{\circ} \mathrm{C}$ until analysis. Samples were homogenously mixed prior to laboratory analysis. A 30-g field-moist soil subsample was brought to $50 \%$ water holding capacity and analyzed for SMBC using the chloroform fumigation-incubation method (Horwath and Paul, 1994; Franzluebbers et al, 1999).

Some part of soil sample was dried in an oven at $100^{\circ} \mathrm{C}$ 
till constant weight. It was crumbled with thumbs and sieved through $2 \mathrm{~mm}$ sieve. Meanwhile, bulk density of soil sample was taken. The remaining particles were weighed, sieved and stored for further analyses.

\section{Sample Analysis}

\section{Determination of total organic carbon}

Soil organic carbon was analyzed from stored sample by the Walkley-Black (1934) Chromic Acid Wet Oxidation Method. Soil sample was ground, dried, passed through 2 $\mathrm{mm}$ sieve and the bulk density and moisture contents were determined. The dried soil sample was sieved through $0.42 \mathrm{~mm}$ sieve and about $0.5 \mathrm{~g}$ (to give $10-20 \mathrm{mg}$ carbon) weighed and transferred to $250-\mathrm{ml}$ conical flask. $10 \mathrm{ml}$ of $1 \mathrm{~N} \mathrm{~K}_{2} \mathrm{Cr}_{2} \mathrm{O}_{7}$ and $20 \mathrm{ml}$ of conc $\mathrm{H}_{2} \mathrm{SO}_{4}$ were added in the flask with swirling to disperse the soil. A $200 \mathrm{C}$ thermometer was inserted inside the flask and heated on a gas burner over asbestos gauze. As temperature of $135 \mathrm{C}$ was reached (about $0.5 \mathrm{~min}$ ), the flask was set aside to cool slowly on an asbestos sheet in a fume cupboard. After $30 \mathrm{~min}, 200 \mathrm{ml}$ of deionized water was added and titrated with $\mathrm{FeSO}_{4}$ using ferroin indicator. Two blank titrations were performed in the same manner. The organic carbon (\%) and total organic carbon were calculated using the equations $(\mathrm{C} 2)$ and $(\mathrm{C} 3)$ respectively.

$$
\text { Organic Carbon }=\frac{0.003 \times \mathrm{N} \times 10 \mathrm{ml} \times(1-\mathrm{T} / \mathrm{S}) \mathrm{X} 100}{\mathrm{ODW}}-\frac{3(1-\mathrm{T} / \mathrm{S})}{\mathrm{W}} \ldots \ldots \ldots \ldots(\mathrm{C}
$$

$$
\text { Soil Organic Carbon }(\mathrm{SOC})=\text { organic carbon content }(\%) \text { of soil } \times \text { soil bulk density }
$$

$$
\left(\mathrm{g} / \mathrm{cm}^{3}\right) \times \text { thickness of horizon }(\mathrm{cm}) \text {. }
$$

\section{Laboratory Analysis for microbial biomass carbon} Microbial biomass $\mathrm{C}$ and $\mathrm{N}$ were determined using the fumigation extraction methods (Brookes et al., 1985; Vance et al., 1987). The filtered soil extracts of both fumigated and unfumigated samples were analyzed for organic $\mathrm{C}$ using the acid dichromate method (Vance et al., 1987). Soil Microbial Biomass Carbon (SMBC) was estimated as BCD 2.64 EC (Vance et al., 1987), where BCD (Biomass Carbon Density) and EC (extractable carbon) were calculated as the difference between carbons extracted from fumigated and unfumigated samples, both expressed in the same measurement unit.

\section{Fumigation}

Fumigation-extraction method was used to measure microbial biomass carbon. 50 gram of oven dried soil sieved through $<2 \mathrm{~mm}$ sieve was weighed in triplicate into glass screw-top jars $(100 \mathrm{ml})$. These jars were placed in a desiccator having moistened tissue paper at the bottom, together with a $25 \mathrm{ml}$ vial of soda lime and a $50 \mathrm{ml}$ beaker containing $30 \mathrm{ml} \mathrm{CHCl}{ }_{3}$ and 2-3 anti-bumping granules. The desiccator was evacuated using air pump until $\mathrm{CHCl}_{3}$ was boiling vigorously. It was continued for 2 minutes. The valve was then closed and the pump was detached. The desiccator was placed at $25 \mathrm{C}$ in a dark room for $24 \mathrm{~h}$.

The soil samples, both fumigated and unfumigated, were transferred separately to $350 \mathrm{ml}$ plastic screw-top bottles. $200 \mathrm{ml}$ of $0.5 \mathrm{M} \mathrm{K}_{2} \mathrm{SO}_{4}$ was added and shaken for $30 \mathrm{~min}$ on a reciprocating shaker (200 strokes min-1). The bottles were removed from shaker and filtered through Whatman 42 filter papers. The quantity of extractant (EX) was noted. Three blanks were prepared in the same way.

\section{Microbial Biomass Carbon Measurement}

Filtered extract $(8 \mathrm{ml})$ was placed with $2 \mathrm{ml}$ of $66.7 \mathrm{mM}$ $\mathrm{K}_{2} \mathrm{Cr}_{2} \mathrm{O}_{7}, 70 \mathrm{mg} \mathrm{HgO}$ and $15 \mathrm{ml}$ of a mixture of 2 parts $\mathrm{H}_{2} \mathrm{SO}_{4}$ and one part $\mathrm{H}_{3} \mathrm{PO}_{4}$ in a round bottomed flask. The mixture was boiled gently under reflux for $30 \mathrm{~min}$. Cold blank was not heated. It was then cooled and diluted with $20 \mathrm{ml}$ water. The residual dichromate was measured by back titration with $0.4 \mathrm{M}$ ferrous ammonium sulphate solution using $25 \mathrm{mM}$ 1,10phenanthrone ferrous sulphate complex as an indicator. Extractable $\mathrm{C}$ was calculated using the following equations (Grace et al, 2003):

$$
\begin{aligned}
& \mathrm{C}\left(\mu \mathrm{g} \mathrm{ml}^{-1}\right)=(\mathrm{Hbl}-\mathrm{S}) / \mathrm{Cbl} \times \mathrm{N} \times \mathrm{Q} / \mathrm{A} \times \mathrm{B} \times 1000 \\
& \mathrm{Hbl}-\mathrm{S} / \mathrm{Cbl} \times 3.33 \times 10^{-5} \\
& \mathrm{C} \mu \mathrm{g} \mathrm{g}^{-1} \mathrm{OD} \text { Soil }=\frac{\mathrm{C}\left(\mu \mathrm{g} \mathrm{ml}^{-1} \times \mathrm{EX}+\mathrm{MC}\right.}{\mathrm{DWt} \text { Soil }} \\
& \text { Where: } \\
& \mathrm{EX}=\text { Quantity of extractant } \\
& \mathrm{MC}=\text { Moisture content of soil used } \\
& \mathrm{DWt}=\text { Dry weight of soil used }
\end{aligned}
$$$$
\mathrm{C} \mu \mathrm{gg}^{-1} \text { OD Soil }=\frac{\mathrm{C}\left(\mu \mathrm{g} \mathrm{m} \mathrm{l}^{-1} \times \mathrm{EX}+\mathrm{MC}\right.}{\mathrm{DWt} \text { Soil }}
$$ 


\section{Statistical Analysis}

All experimental data analyses were carried out by using IBM-SPSS statistics version 20 (IBM-SPSS, 2011) software. Three-way ANOVA was used to analyze the main and interactive effects of grazing intensities, legume treatment and soil profiles on ratio of microbial biomass carbon to soil organic carbon (SMBC:SOC). Significance levels were set at $\alpha=0.05$ for all tests. Fisher's least significant difference (LSD) was used to test the significance of means that were considered significantly different at $5 \%$ level of significance.

\section{Results and Discussion}

The ratio of SMBC to SOC varied from $0.03 \pm 0.01$ to $0.14 \pm 0.02$ (mean \pm S.E.). The heavily grazed plothad less value of ratio than occasionally grazed and ungrazed plots. The difference was statistically significant $(F=7.32, p=0.001)$. However, the difference between the ratio of occasionally grazed and ungrazed plot was insignificant $(p>0.05)$. When observing on legume treatment, the ratio of SMBC to SOC in terms of percentage was 61.5 more in legume seeding sub-plot than non-legume sub-plot $(F=52.28, p=$ 0.000 ), regardless of grazing intensity (Figure $2 \mathrm{C}$ ). The ratio of SMBC to SOC was more or less similar $(0.085 \pm$ 0.003 ) for all soil depth of the study area (Figure 2).

SMBC and SOC were observed as follows: The legume seeding sub-plothad significantlyhighervalue thannon-legumesub-plot in all grazing intensities viz. heavily grazed $(F=9.7, p=$ $0.003)$, occasionally grazed $(F=3.29, p=0.07)$ and ungrazed $(\mathrm{F}=57.66, \mathrm{p}=0.000)$ (Fig. $2 \mathrm{~A})$. Similarly, the differences among the ratio of SMBC to SOC for top soil, sub soil and bottom soil were insignificant in heavily grazed and ungrazed sub-plots, while the difference was marginal in occasionally grazed area $(F=7.72, p=$ 0.001)(Fig. 2 B). The ratio differences of top soil, sub soil and bottom soil were insignificant in legume seeding and non-legume sub-plots (Fig. 2 C).

The relationship between soil organic carbon and SMBC showedasignificantcorrelation $\left(\mathrm{R}^{2}=0.21, \mathrm{p}=0.00\right)$ (Fig.2D).
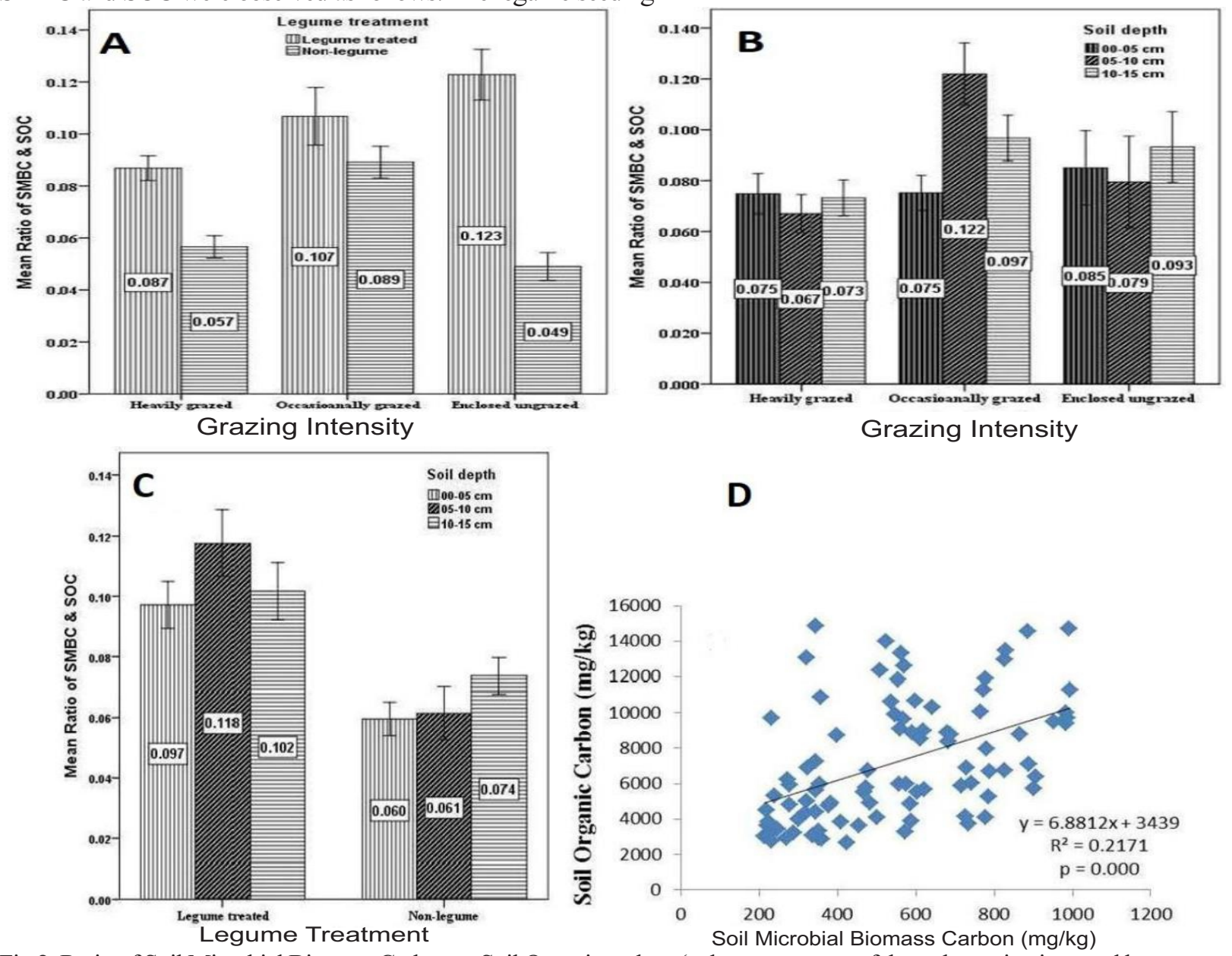

Fig 2. Ratio of Soil Microbial Biomass Carbon to Soil Organic carbon (values are means of three determinations and bars represent standard errors) (A) Interaction effects of legume treatment and grazing intensity (B) Interaction effects of grazing intensity and soil depth and (C) Interaction effects of legume treatment and soil depth on the ratio(D) Relation between Soil organic carbon and soil microbial biomass carbon. 
The ratio of microbial biomass carbon to soil organic carbon (SMBC: SOC) in soil has been proposed as a sensitive measure of soil health, since it represents a combination of microbial activity and key soil resource (Anderson and Domsch, 1989; Sparling, 1992). The grazing intensity and legume treatment impact on the ratio of SMBC to SOC regardless of the soil depth. It suggested that the variability of SMBC to SOC ratios is inconsistent at all grazing intensity and legume treatment but consistent at all soil profiles. Holt (1997) noted that microbial carbon was more sensitive to grazing pressure than soil organic carbon.

Present findings of SMBC: SOC ratios are higher to those reported for tall grass prairie (0.028) in the United States (Rice et al, 1994), $C_{3}$ grasslands (0.024) in Canada (Carter, 1986), and Pampas grasslands (0.03) in Argentina (Alvarez et al, 1998). This suggests that the microbial biomass carbon is comparatively high in Himalayan rangeland.

Similar significant positive linear correlations have been reported between microbial biomass carbon and soil organic carbon for diverse soils (Anderson and Domsch, 1989; Witter et al, 1993; Weigand et al, 1995). Greater $\mathrm{MBC}$ as a result of higher soil water and litter in occasional grazing of rangeland supports the above argument. The increase of root productivity and soil temperature are also the reasons leading towards greater MBC (Harris et al, 2007). The higher MBC content indicated a greater carbon turnover and greater abundance of metabolizable $\mathrm{C}$ in ecosystem (Kieft, 1994).

When equilibrium is attained, input to any particular C compartment is equal to output, and there is no further accumulation or decrease of organic matter in the system. When the management of as oil is changed, the soil microbial biomass responds more quickly than the amount of organic matter does in the soil. Thus, the ratio of microbial biomass carbon to total organic carbon will increase for a time if the input of organic matter to a soil is increased and vice versa.

\section{Conclusions}

The heavily grazed plot had significantly less ratio of soil microbial biomass carbon to soil organic carbon than occasionally grazed and ungrazed plots. Similarly, value of the ratio was significantly high on legume seeding plot than non-legume plot, but it was insignificant difference at all soil depth. The relationship between soil organic carbon and SMBC showed significant correlation.

\section{Acknowledgement}

We would like to thank Mr. J. B. Limbu, and Mr. Pasang Sherpa who accompanied us for research field work. We extend our thanks to Mr. R. Bhattarai and Mr. B. Adhikari for laboratory work assistance. One of the authors (D.K.) is grateful to the University Grants Commission, Nepal for the research fellowship.

\section{References}

Allison FE. Soil organic matter and its role in crop production. In 'Developmentsin Soil Science 3, Elsevier: New York, 1973.

Anderson TH and Domsch KH. Ratios of microbial biomass carbon to totalorganic carbon in arable soils. Soil Biology \& Biochemistry, 1989, 21: 471-9.

Blake GR and Hartge KH. Bulk Density. In A. Klute (Ed.), Methods of soil analysis. Part 1. (pp 363375), Madison, WI:Am Soc Agron, 1986.

Brookes PC, Landman A, Pruden G and Jenkinson DS. Chloroform fumigation and the release of soil Nitrogen: a rapid direct extraction method to measure microbial biomass Nitrogen in soil. Soil biology and biochemistry, 1985, 17 (6), 837-42.

Dormaar JF and Willms WD. Effects of grazing and cultivation onsome chemical properties of soils in the mixed prairie. J. Range Manage, 1990, 43:456-60.

Frank AB, Tanaka DL, Hofmann L and Follett RF. (1995) Soil carbon andnitrogen of northern Great Plains grasslands as infl uenced by long-termgrazing. J. Range Manage, 1995, 48:470-4.

Franzluebbers AJ. Potential C and $\mathrm{N}$ mineralization and microbial biomass from intact and increasingly disturbed soils of varying texture. Soil Biology \& Biochemistry, 1999, 31, 1083-90.

Ganjegunte GK, Vance GF, Preston CM, Schuman GE, Ingram LJ, Stahl PD and Welker JM. Influence of different grazing managementpractices on soil organic carbon constituents in a northern mixedgrassprairie. Soil Sci Soc Am J, 2005, 69:1746-56.

Grace C, Hart M, and Brookes PC. Laboratory Manual of the Soil Microbial, 2003. 
Holt JA. Grazing pressure and soil carbon, microbial biomass and enzymeactivities in semi-arid northeastern Australia. Applied Soil Ecology, 1997, 5: 143-9.

Horwath WR, and Paul, E. A. (1994). Microbial biomass. In R. W. Weaver, J. S. Angle \& P. S. Bottomley (Eds), Methods of Soil Analysis, Part 2: Microbiological and Biochemical Properties (pp. 753-773). Madison, USA: Soil Science Society of America.

IBM, IBM SPSS Statistics for Windows (Version 20.0). Armonk, NY: IBM Corp, 2011

Naeth MA, Bailey AW, Pluth DJ, Chanasyk DS and Hardon RT. Grazing impacts on litter and soil organic matter in mixed prairie andfescue grassland ecosystems in Alberta. J. Range Manage, 1991, 44, $7-12$.

Nielsen NM, Winding A and Binnerup $S$, Microorganisms as indicators of soilhealth. Ministry of the Environment. National Environmental Research Institute, 2002, 388: $15-16$.

ShariffAR, Biondini ME and Grygiel CE (1994) Grazing intensity effectson litter decomposition and soil nitrogen mineralization. J Range Manage, 1994, 47:444-9.

Parton WJ, Morgan JA, Kelly RH and Ojjma DS. Modeling soil $\mathrm{C}$ responses to environmental change in grassland systems, 2001, pp 371-398.In R.F.
Follett et al (eds) The potential of US grazing lands to sequestercarbon and mitigate the greenhouse effect. Lewis Publ, Boca Raton, FL.

Paul EA and Clark FE (1996) Soil Microbiology and Biochemistry Academic Press,New York, USA, 1996.

Powlson DS, Brookes PC, and Christensen BT. Measurement of soil microbialbiomass provides an early indication of changes in total soil organic matter due to strawincorporation. Soil Biol Biochem, 1987, 19, 159-64.

Powlson DS, and Jenkinson DS. A comparison of the organic matter, biomass, adenosine triphosphate and mineralizable nitrogen contents of ploughed and direct-drilledsoils. J Agric Sci, 1981, 97, 713-21.

Vance ED, Brookes PC and Jenkinson DS. An extraction method for measuring soil microbial biomass $\mathrm{C}$. Soil biology and Biochemistry, 1987, 19(6), 703707.

Walkley A, \& Black IA (1934). An examination of Degtjareff method for determining soil organic matter and a proposed modification of the chromic acid titration method. Soil Science 1934, 27, 29-38.

Wang C \& Long R. Changes in soil organic carbon and microbial biomasscarbon at different degradation successional stages of alpine meadows in theheadwater region of three rivers in China. Journal of Applied \& Environmental Biology, 2008, 14:225-30. (in Chinese with English abstract). 